\title{
Note \\ COMPARATIVE MORPHOLOGICAL ANALYSIS OF CHERRY TOMATO FRUITS FROM THREE CROPPING SYSTEMS
}

\author{
Sônia Cachoeira Stertz ${ }^{1,2 *}$; Ana Paula do Espírito Santo ${ }^{3}$; Cleusa Bona ${ }^{4}$; Renato João Sossela \\ de Freitas ${ }^{1}$ \\ ${ }^{1}$ UFPR - Depto. de Engenharia Química, C.P. 19011 - 81531-990 - Curitiba, PR - Brasil. \\ ${ }^{2} U F P R$ - Programa de Pós-Graduação em Tecnologia de Alimentos. \\ ${ }^{3} U F P R$ - Departamento de Farmácia-Bioquímica. \\ ${ }^{4}$ UFPR - Depto. de Botânica, Curitiba. \\ *Corresponding author<stertz@ufpr.br>
}

\begin{abstract}
Attempts to meet produces market demand are not always followed by research reports showing the impact of novel, intensive cropping systems on the environment, human and animal health, and eventual chemical and structural changes of plants. This work carries a comparative evaluation of the morphology and anatomy of cherry tomato fruits obtained from organic, conventional and hydroponic cropping systems. Fruits were collected at the free market in the greater Curitiba, Paraná, Brazil. For each culture method, 50 fruits their weight, diameter and volume measured. For the anatomical analysis, samples of the pericarp of ten fruits were excised and embedded in glycol methacrylate; $6-\mu \mathrm{m}$ cuts were then obtained, stained with toluidine blue, and mounted on permanent glass slides. The anatomical analysis and illustrations were performed in Olympus and Zeiss photonic microscope. Samples obtained from the organic cropping system presented the highest mass, diameter, volume and density. The pericarp of fruits, obtained from the conventional cropping system presented larger but less abundant cells in comparison to the pericarp of the hydroponic and organicproduced fruits.
\end{abstract}

Key words: Lycopersicon esculentum, morphology, organic, hydroponic, conventional

\section{ANÁLISE MORFOLÓGICA COMPARATIVA DE FRUTOS TOMATE CEREJA PROVENIENTES DE TRÊS SISTEMAS DE CULTIVO}

\begin{abstract}
RESUMO: A ciência agrícola buscou novas formas de cultivo para atender às exigências de mercado e dividiu-se em três grandes vertentes: os sistemas de cultivo orgânico, convencional e hidropônico. Todavia, esses avanços nem sempre foram acompanhados por pesquisas que objetivassem apontar o impacto de uma nova técnica agrícola sobre o ambiente, a saúde humana e animal e aos próprios vegetais em seus aspectos químicos e estruturais. Este trabalho tem por objetivo o estudo comparativo da morfo-anatomia do fruto do Lycopersicon esculentum var. cerasiforme (Duval) A. Gray, cultivado nos sistemas orgânico, convencional e hidropônico. Os frutos foram coletados no comércio varejista da Região Metropolitana de Curitiba, Paraná, Brasil. Para cada cultivo foram analisados 50 frutos. Cada fruto foi pesado e teve o diâmetro e volume medidos. Para análise anatômica foram retiradas amostras do pericarpo de dez frutos, que foram embebidas em glicol metacrilato, seccionadas com $6 \mu \mathrm{m}$ de espessura, coradas com azul de toluidina e montadas em lâminas permanentes. A análise anatômica e as ilustrações foram feitas em microscópio fotônico Olympus e Zeiss com câmara fotográfica acoplada. As amostras obtidas pelo sistema de cultivo orgânico apresentaram maior massa, diâmetro, volume e densidade. O pericarpo, dos frutos do cultivo convencional, apresentou células maiores e em menor número em relação ao pericarpo dos frutos hidropônicos e orgânicos.

Palavras-chave: Lycopersicon esculentum, morfologia, orgânico, hidropônico, convencional
\end{abstract}

\section{INTRODUCTION}

The ecological conscience has grown considerably and the search for low-impact agriculture has stimulated progress in agricultural technology. To meet produces market demands, the crop science has searched for new culture methods, and three great areas emerged: organic, conventional and hydroponics cropping systems.
Paradoxically, advances in agricultural knowledge have not always been followed by research reports pointing the impact of a novel agricultural technique on the environment, human and animal health, and plants chemical, structural and morpho-anatomical features.

Structural and physiological changes on plant organs driven by environmental variations have been long studied (Fahn, 1990; Peterson, 1992). However, most 
available information refers to plants which did not go through systematic cropping, such as the tomato, which can be farmed in conventional, organic or hydroponic systems. Blooming and fruit formation ordinarily come along vegetative growth, justifying intensive cultural treats along the production cycle.

Fruits of cherry tomato Lycopersicon esculentum var. cerasiforme (Dunal) A. Gray are round, similar to a cherry juicy and meaty berry, red when ripe, bigger than $1.5 \mathrm{~cm}$ in diameter (Silva \& Giordano, 2000). Many factors can influence the development of the fruit (Gillaspy et al., 1993). In most plants early fruit development can be divided into three phases, and many factors - physiological, hormonal, genetic, and nutritional - can influence fruits growth and development in each phase. This work carries a comparative evaluation of the morphology and anatomy of the marketable cherry tomato fruits, obtained from organic, conventional or hydroponics cropping systems.

\section{MATERIAL AND METHODS}

Fruits were collected in the free market at greater Curitiba - Paraná, Brazil, packed in plastic boxes, suited for commercialization. Diameter, mass, volume and density of 50 fruits were measured, and ten fruits were randomly sampled for measuring thickness of the pericarp and to tissues analysis.

Diameter of fruits was measured with pachymeter (Mitutoyo; nearest $0.02 \mathrm{~mm}$ ). Fruits were weighted on analytical scale and fruits volume was measured by volume displacement in a $150-\mathrm{mL}$ test tube, filled with tap water up to the $100 \mathrm{~mL}$ mark..

Samples of the pericarp $\left(0.5 \mathrm{~cm}^{2}\right)$ were collected from the medium portion of the fruit, fixed for 48 hours in FAA 50 (ethanol 50\%: acetic acid: formol 18:1:1 v/v/ v) (Johansen, 1940). After dehydration in ethanolic series, samples were embedded in glycol methacrylate (JB4, Polysciences $^{\circledR}$ ) (Feder \& O’Brien, 1968); 6- $\mu$ m thick cuts were taken with rotary microtome (Olympus CUT 4055), stained with toluidine blue (O'Brien et al., 1964) or basic fuchsin and astra blue (Brito \& Alquini, 1997), and submitted to photonic microscopy through micrometric ocular (Olympus). Photomicrographs were taken in a Zeiss MC80 microscope.
The JMP ${ }^{\circledR}$ statistical software was used to calculate averages, standard deviation and coefficients of variation. Data were submitted ANOVA and differences between means compared through the Tukey-Kramer test $(\alpha=0.05)$.

\section{RESULTS AND DISCUSSION}

All collected fruits presented two carpels and fresh pericarp, with outer epidermis and collenchymous tissue (exocarp), many layers of large, thin-walled parenchymatic cells and the inner epidermis (endocarp) (Roth, 1977). Fruits from plants organically grown had $31 \%$ higher mass than fruits from other culture systems $(P<0.05)$. Diameters of the organic and hydroponic grown fruits were similar and approximately $28 \%$ bigger than the diameter of conventionally grown fruits. The hydroponic and conventionally produced fruits were circa $24 \%$ larger in volume than the organic fruits (Table 1).

Density of the organic and hydroponic cherry tomato fruits is similar, and bigger than the density of the conventional culture fruits $(P<0.05)$ (Table 1$)$. The mean thickness of the organically grown cherry tomato pericarp was $3.61 \mathrm{~mm}$; for hidroponically grown fruits, $3.70 \mathrm{~mm}$. No structural differences were observed in the endocarp and exocarp of fruits. The pericarp of hydroponics fruits presented a parenchymatic mesocarp with larger quantity of small-sized cells, which differed from the conventionally grown culture in structure (Figure 1). This characteristic probably impresses the biggest density of the organic and hydroponic fruit when compared to the conventional culture fruit.

Tomato fruits present broad morphological variation, and the number and size of the pericarp cells might be influenced by several factors (Gillaspy et al., 1993). Therefore, difference in size of the mesocarp cells were caused by the different cropping systems.

The organic cherry tomato presented highest mass and volume in comparison to fruits grown under the other two cropping system, possibly as result, among several factors, of soil's richness in organic substances, with stronger water retention capacity and adequate phosphorus and potassium contents, important elements in the process of weight gain of fruits (Sganzerla, 1995). In addi-

Table 1 - Mass, diameter, volume and density $(\mu \pm$ SD) of cherry tomato fruits from plants cultivated under conventional, hydroponic or organic system.

\begin{tabular}{lccc}
\hline Determinations & Conventional & Organic & Hydroponic \\
\hline Mass $(\mathrm{g})$ & $13.23(2.50) \mathrm{b}$ & $17.33(3.30) \mathrm{a}^{*}$ & $14.50(3.12) \mathrm{b}$ \\
Diameter $\left(\mathrm{mm}^{2}\right)$ & $24.84(2.21) \mathrm{b}^{* *}$ & $31.77(1.66) \mathrm{a}$ & $30.06(2.18) \mathrm{a}$ \\
Volume $(\mathrm{mL})$ & $13.73(2.41) \mathrm{b}$ & $17.00(3.23) \mathrm{a}^{*}$ & $14.30(2.91) \mathrm{b}$ \\
Density $\left(\mathrm{g} \mathrm{mL}^{-1}\right)$ & $0.96(0.03) \mathrm{b}^{*}$ & $1.02(0.05) \mathrm{a}$ & $1.01(0.04) \mathrm{a}$ \\
\hline
\end{tabular}

Means followed by identical letters do not differ; Tukey-Kramer test; * $(P<0.001)$; ** $(P<0.05)$.

Sci. Agric. (Piracicaba, Braz.), v.62, n.3, p.296-298, May/June 2005 


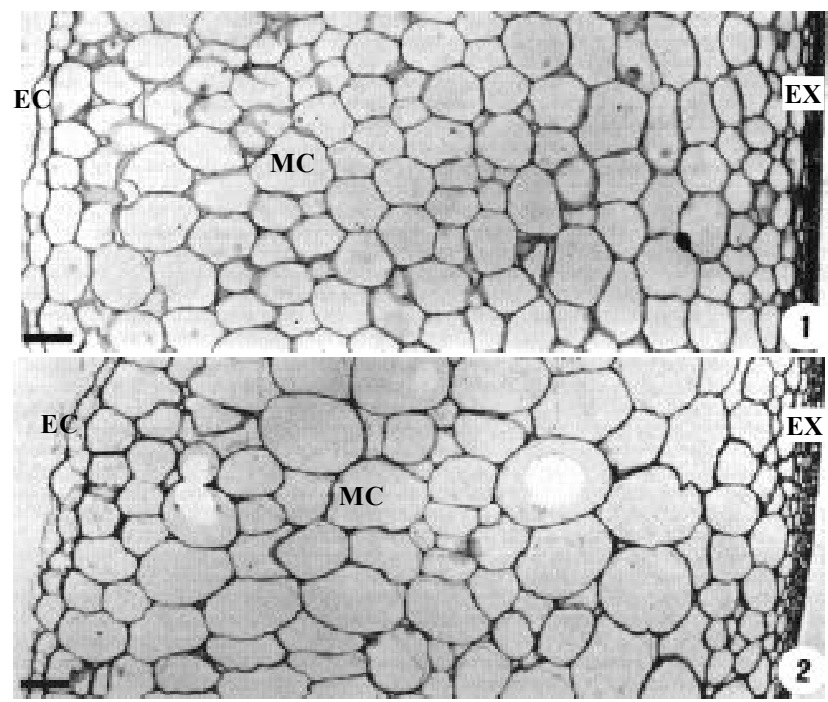

Figure 1 - Pericarp transversal sections of cherry tomato; (1) hydroponic fruit; (2) conventional fruit (bar $=200 \mu \mathrm{m}) . \mathrm{EC}-$ endocarp; MC - mesocarp; EX - exocarp.

tion, application of fungicides and herbicides might affect gain in fresh weight of fruits grown in conventional and hydroponics system, as shown by Thomson \& Ockey (2002) and Van Iersel \& Bugbee (2002).

\section{ACKNOWLEDGMENTS}

To Fundação Araucária - PR, for the financial support (Project 567) and to Prof. James J. Roper, for the assistance with the statistical analysis of data.

\section{REFERENCES}

BRITO, C.J.F.A.; ALQUINI, Y. A new method for staining botanical material embedded in glycol methacrylate (GMA). Arquivos de Biologia e Tecnologia, v.4, p.949-950, 1997.

FAHN, A. Plant anatomy. 3.ed. Oxford: Pergamon Press, 1990. 588p.

FEDER, N.; O`BRIEN, T.P. Plant microtechnique: some principles and methods. American Journal of Botany, v.55, p.123-142, 1968.

GILLASPY,G.; BEN-DAVID, H.; GRUISSEM, W. Fruits: A developmental perspective. The Plant Cell, v.5, p.1439-1451, 1993.

JMP $^{\circledR}$. JMP Scripting Guide, Version 5. SAS Institute Inc., Cary, 2002. 1 CDROM.

JOHANSEN, D.A. Plant microtechnique. New York: Mc Graw Hill Book, 1940. 523p.

O‘BRIEN, T.P.; FEDER, N.; McCULLY, M.E. Polychromatic staining of plant cell walls by toluidine blue. Protoplasma, v.59, p.368-373, 1964.

PETERSON, R.L. Adaptations of root structure in relation to biotic and abiotic factors. Canadian Journal of Botany, v.70, p.661-675, 1992.

ROTH, I. Fruits of Angiosperms. Berlin-Stuttgart: Gebrüder Borntraeger, 1977. 666p.

SGANZERLA, E. Nova agricultura. A fascinante arte de cultivar com os plásticos. 5.ed. Esteio: Ed. Plasticultura Gaúcha Ind. e Com. Ltda., 1995. $338 \mathrm{p}$.

SILVA, J.B.C.; GIORDANO, L.B. Tomate para processamento industrial. 1.ed. Brasília: Embrapa, 2000. 200p.

THOMSON, S.V.; OCKEY, S.C. Herbicide injury to yard and garden plants. Logan: Utah State University. Available in: <http:// www.biology.usu.edu.> Access in April 01, 2002.

VAN IERSEL, M.W.; BUGBEE, B.G. Fungicide effects on gas exchange and growth of bedding plants. Logan: Utah State University. Available in <http://www.usu.edu. $>$ Access in April 01, 2002.
Received May 05, 2004 Accepted April 04, 2005 